\title{
Campylobacter upsaliensis isolated from young dogs with and without diarrhea
}

\author{
Campylobacter upsaliensis isolado de cães \\ jovens com e sem diarréia
}

Dear Editor,

Campylobacter upsaliensis is considered a human enteropathogen associated with diarrhea and bacteremia $a^{378121415}$. This is an atypical species of Campylobacter genus as it is thermophilic, weakly catalase-positive, and generally sensitive to cephalosporins. Immunosuppressive factors seem to be of major importance in triggering the disease ${ }^{511}{ }^{16}$. Cats and dogs are considered the major carriers for humans ${ }^{4} 717$, more frequently in under 12-month-old dogs ${ }^{4}$. In Brazil, studies on dogs as potential C. upsaliensis carriers for humans are scarce. We studied the isolation frequency in $100 \mathrm{dogs}$ with diarrhea and 100 dogs without diarrhea; all animals were less than 12 months old.

Dog feces were submitted to two parallel procedures: 1) filtration technique - one gram of feces was suspended in a test tube with $9 \mathrm{ml}$ saline solution, vigorously homogenized for $1 \mathrm{~min}$, centrifuged at 2,500 rpm for $5 \mathrm{~min}$, and filtered using $0.65 \mathrm{mM}$ cellulose acetate membrane filter. Three drops from this filtrate were grown on Petri dishes in sodium thioglycolate agar supplemented with $20 \%$ bovine blood and incubated at $37^{\circ} \mathrm{C}, 2$ ) Direct growth - one aliquot of feces was grown in smears in the same agar with Butzler selective supplementation (bacitracin, novobiocin, cycloheximide, colistin and cefazoline) and incubated at $43^{\circ} \mathrm{C}$. In both procedures, the plates were examined with a phase-contrast microscope (1000 X) for morphological evaluation of vibrion characteristics and typical spirillum movement. After presumptive diagnosis, these colonies were replicated in Tarozzi medium and incubated at $37^{\circ} \mathrm{C}$ for 72 hours to obtain the inoculum, with density adjusted to 1 MacFarland standard turbidity (3x108 CFU/mL). Definitive diagnosis was made using biochemical characteristics from following tests ${ }^{10}$ : catalase

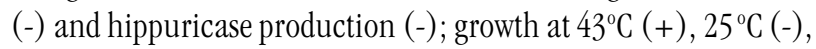
in $1 \%$ glycine $(-)$, and in $3.5 \% \mathrm{NaCl}(-)$; resistance to nalidixic acid (-) and cephalothin (-); production of $\mathrm{H}_{2} \mathrm{~S}$ with (-) or without cysteine (-); and tolerance to 2'3'5' triphenyltetrazoline chloride (-). The animals with diarrhea showed $3(3 \%)$ C. upsaliensis strains and the diarrhea-free $2(2 \%)$. Our results were relatively lower than other data in literature, suggesting heterogeneity of this bacterium isolation frequency ${ }^{249}$. To increase the possibility of C. upsaliensis detection, a filtration technique should be used on a routine basis; as has already been reported ${ }^{13}$. C. upsaliensis isolation from dogs highlights the risk of zoonosis, especially in Brazil, although no reports were found in literature.

\section{José Rafael Modolo ${ }^{1}$ and Rogerio Giuffrida ${ }^{1}$}

\section{ACKNOWLEDGEMENTS}

The authors wish to thank Fundação de Amparo à Pesquisa de São Paulo for financial support and Ms. Tânia Maria Martins and Adriana Cristina Pavan Vieira for their valuable technical assistance.

\section{REFERENCES}

1. Albert, MJ, Tee W, Leach A, Asche V, Penner JL. Comparison of blood-free medium and a filtration technique for isolation of Campylobacter spp. from diarrhoeal stools of hospitalised patients in central Australia. Journal of Medicine Microbiology 37:176-179, 1992.

2. Baker J, Barton MD, Lanser J. Campylobacter species in cats and dogs in South Australia. Australian Veterinary Journal 77:662-666, 1999.

3. Bourke B, Chan VL, Sherman P. Campylobacter upsaliensis: waiting in the wings. Clinical Microbiology Reviews 11:440-449, 1998.

4. Burnens AP, Ageloz-Wick B, Nicolet J. Comparison of Campylobacter carriage rates in diarrheic and healthy pet animals. Zentralblatt fur Veterinaermeddizin [B] 39:175-180, 1992.

5. Carnahan AM, Beadiling J, Watsky D, Ford N. Detection of Campylobacter upsaliensis from a blood culture by using the BacT/Alert system. Journal of Clinical Microbiology 32;2598-2599, 1994

6. Goossens H, Vlaes L, Butzler JP, Adnet A, Hanicq P, N'Jufom S, Massart D, De Schrijver G, Blomme W. Campylobacter upsaliensis enteritis associated with canine infections. Lancet 337:1486-1487, 1991.

\footnotetext{
1. Disciplina de Panejamento de Saúde Animal e Veterinária Preventiva do Departamento de Higiene Veterinária e Saúde Pública da Faculdade de Medicina Vetrinária e Zootecnia da Universidade do Estado de São Paulo, Botucatu, SP.

Supported by grants from FAPESP (Fundação de Amparo à Pesquisa do Estado de São Paulo)

Address to: Dr José Rafael Modolo. Caixa Postal 524, 18618-000 Botucatu, SP.

Tel: 14 6802-6270, Fax: 14 6802-6075

e-mail: jrmodolo@fmvz.unesp.br

Recebido para publicação em 14/8/2002.

Aceito em 13/11/2003
} 
7. Goossens H, Vlaes L, De Boeck M, Pot B, Kerstrs K, Levy J, De Mol P, Butzler JP, Vandamme P. Is "Campylobacter upsaliensis" an unrecognized cause of human disease? Lancet 335:584-586, 1990.

8. Grossens H, Giesedorf BA, Vandamme P, Vlaes L, Van Den Borre C, Koeken A, Quint WG, Blomme W, Hanicq P, Koster DS. Investigation of an outbreak of Campylobacter upsaliensis in day care centers in Brussels: analysis of relationships among isolates by phenotypic and genotyping methods. Journal of Infectious Diseases 172:1298-1305, 1995.

9. Hald B, Madsen M. Healthy puppies and kittens as carriers of Campylobacter spp, with special reference to Campylobacter upsaliensis. Journal of Clinical Microbiology 35:3351-3352, 1997.

10. Holt JG, Krieg NR, Sneath PHA, Stanley JT, Willians ST. Bergey's manual of determinative bacteriology. $9^{\text {th }}$ edition, Philadelphia: Willians \& Wilkins, p. 799, 1994.

11. Jerkin GA, Tee W. Campylobacter upsaliensis-associated diarrhea in human immunodeficiency virus-infected patients. Clinical Infectious Diseases 27:816-821, 1998.

12. Jimenez $\mathrm{SG}$, Heine $\mathrm{RG}$, Ward PB, Robins-Browne RM. Campylobacter upsaliensis gastroenteritis in childhood. Pediatric Infectious Diseases Journal 18: 988-992, 1999
13. Lopez L, Castillo FJ, Clavel A Rubio MC. Use of a selective medium and a membrane filter method for isolation of Campylobacter species from Spanish paediatric patients. European Journal of Clinical Microbiology Infectious Diseases 17: 489-492, 1998.

14. Mooney A, Clyne M, Curran T, Doherty D, Kilmartin B, Bourke B. Campylobacter upsaliensis exerts a cytolethal distending toxin effect on HeLa cells and lymphocytes. Microbiology 147:735-743, 2001.

15. Musmanno RA, Russi M, Figura N, Guglielmetti P, Zanchi A, Signori R, Rossolini A. Unusual species of campylobacters isolated in the Siena Tuscany area, Italy. New Microbiology 21:15-22, 1998.

16. Snijders, F, Kuijper EJ, De Wever B, Van Der Hoek L, Danner SA, Dankert J. Prevalence of Campylobacter-associated among patients infected with immunodeficiency virus. Clinical Infectous Diseases 24:1107-1113, 1997.

17. Steinhauserova I, Fojtikova K, Klimes J. The incidence and PCR detection of Campylobacter upsaliensis in dogs and cats. Letters in Applied Microbiology 31 209-212, 2000 